\title{
The Effect of Based Services Medication Therapy Management on Treatment Adherence and Quality of Life of Diabetes Mellitus Patients
}

\author{
Rachma Malina ${ }^{1 *}$, Nanang Munif Yasin ${ }^{2}$, Chairun Wiedyaningsih ${ }^{2}$ \\ 1. Magister Farmasi Klinik, Fakultas Farmasi, Universitas Gadjah Mada, Yogyakarta \\ 2. Fakultas Farmasi, Universitas Gadjah Mada, Yogyakarta \\ Submitted: 23-07-2020 Revised: 19-09-2020 Accepted: 30-09-2020 \\ Korespondensi : Nanang Munif Yasin : Email : nanangy@yahoo.com
}

\begin{abstract}
Diabetes mellitus is a chronic metabolic disorder that is characterized by hyperglycemia. Diabetes mellitus need appropriate therapeutic management, because it can cause complications. On of the services that can do to improve diabetes control is Medication Therapy Management (MTM). MTM is a new service that will help pharmacist to improve patient adherence and quality of life. This study aims to determine the effect of based services MTM on treatment adherence and quality of life in patients with diabetes mellitus. This study was an experimental study using a quasi-experimental with one group pretest and posttest design which was conducted in Tegalrejo, Jetis and Gedontengen Health Center Yogyakarta City. Variables measured were medication adherence using the Morisky-Green Levine Medication Adherence Scale (MGLS) questionnaire and quality of life using Diabetes Quality of Life Clinical Trial Questionnaire (DQLCTQ) before and after MTM services. The effect of MTM on medication adherence was analyzed using Wilcoxon test and the effect of MTM on quality of life using Paired T-Test. The patients participate in this study were 20 people, with average score of adherences before application of MTM was $2.20 \pm 0.410$ to $1.80 \pm 0.616$ after the application of MTM $(P=0.005)$ and the average of the patient's quality of life was 73.82 \pm 7.918 , increased to $76.42 \pm 5,623$ after MTM service $(P=0.033)$. Statistically mean, there is a difference in adherence and quality of life before and after MTM services. Therefore, it can be concluded that MTM-based services performed by pharmacists have a significant effect on improving medication adherence and quality of life for DM patients. Moreover, it can facilitate monitoring patient therapy, and identification of problems related to the treatment.

Keywords: Diabetes mellitus; adherence; quality of life; medication therapy management; MTM
\end{abstract}

\section{INTRODUCTION}

Chronic disease is a condition that contributes greatly to health, including the patient's clinical, humanistic, and even economic conditions. One of the chronic diseases that receive special attention and must be managed properly is diabetes mellitus $(\mathrm{DM})^{1}$. It's due to the fact that diabetes has impacts on the patient's well-being, productivity and quality of life $^{2}$. The prevalence of diabetes all over the world continues to increase. In 2000, the prevalence of DM for all age groups reached $2.8 \%$ and is predicted to increase to $4.4 \%$ in $2030^{3}$. According to the Riskesdas 2018 data, in Indonesia, there was an increase in the prevalence of DM based on doctors' diagnosis at $\geq 15$ years of age by $2 \%$ from the previous prevalence of DM in 2013, where DKI Jakarta Province had the highest DM prevalence of $3.4 \%$ and followed by the Special Region of
Yogyakarta (DIY) with $3.1 \%$ in $2018^{4}$. Yogyakarta's health profile shows that DM is included in the top 10 non-communicable diseases with the number of cases and groupings of DM disease as many as 11,736 cases of non-classified DM (DM YTT) and 12,019 cases of insulin-independent diabetes in 20185. Improving DM disease control can be accomplished with regular monitoring and consistent follow-up related to lifestyle modifications, regular blood glucose monitoring and medication adherence. ${ }^{6}$. However, ensuring the adherence to therapy regimens is one of the main challenges in achieving the desired therapeutic goals in DM patients, as DM is a chronic disease that requires various patient-centered collaborative care models to improve the treatment behavior in DM patients.

One of the feasible services is the Medication Therapy Management (MTM) 
service. MTM is a new service provided by health care providers, including pharmacists, to ensure the best therapy results for patients. The objectives of the MTM service are to ensure that the drugs prescribed to patients are consumed appropriately, optimize patients' understanding of drug use, improve patient compliance with prescribed drug therapy, and reduce the risk of drug-related adverse events in order to improve the patient's quality of life.7. MTM includes five main elements, i.e. medication therapy review (MTR), personal medication record (PMR), medication-related action plan (MAP), intervention, and follow up ${ }^{8}$. These elements of MTM are expected to enhance the collaboration and communication between pharmacists, doctors and other health care professionals in caring for patients, as well as optimizing drug use for better results. ${ }^{8}$. Thus, the compliance and good quality of life are achieved for patients, particularly DM patients. Several studies have shown that improvements in the clinical outcome of diabetic patients are achieved through the provision of MTM services by pharmacists. Viswanathan et al., ${ }^{9}$ conducted a review of several studies with Cochrane data sources and International Pharmaceutical Abstracts related to the effectiveness of MTM service interventions provided to outpatients with chronic conditions, and the results showed that MTM improved appropriate drug prescribing, use of appropriate drugs, medication adherence and patient's quality of life ${ }^{9}$. Research conducted by Erku et al., ${ }^{10}$ showed that there was an increase in the compliance of patients who received MTM services by pharmacists ${ }^{10}$. In Indonesia, research related to MTM services has not been widely carried out, but research related to services carried out by pharmacists such as providing education, counseling, or booklets on drug use has been widely carried out and has a good impact on patient treatment. ${ }^{11}$. Presetiawati et al., ${ }^{11}$ and Septiar and Utami ${ }^{12}$ state that counseling by pharmacists increased the adherence and quality of life for DM type 2 patients ${ }^{11,12}$.
In Indonesia, the MTM service has been proclaimed by the government alongside with the Social Insurance Administration Organization (BPJS) since 2017/2018 and has been implemented in several community health centers (puskesmas) in Yogyakarta City. One of them is the public health center, where the research is conducted, that provides MTM services to chronic disease patients, in this case the Referral Patient (PRB). The MTM service uses a sheet containing MTM elements listed by the BPJS, used by the patients every time they visit a public health center. Based on the existing MTM form, problems in filling the form persist due to the large number of sheets that must be filled in by health workers, especially pharmacists. Therefore, it is necessary to simplify the MTM form to facilitate the implementation of MTM in public health centers. Accordingly, this study aims to determine the effect of MTM-based services (simplified MTM) applied by pharmacists on medication adherence and DM patients' quality of life at Yogyakarta city health centers.

\section{METHOD}

This research is an experimental research using a quasi-experimental one group design with pretest and post-test design which was carried out at the Yogyakarta City's Puskesmas Tegalrejo, Jentis and Gedongtengen in March-April 2020. The variables measured in this study were medication adherence and DM patients' quality of life before (Pre-MTM) and after (Post-MTM) receiving MTM-based services. The intervention carried out in this study was in the form of MTM-based services provided by pharmacists to patients. The MTM services provided were in the form of implementing the MTM elements; 1) Assessment, i.e. the collection of information related to patient treatment and problems related to patient treatment (Element of Medication Therapy Review) and documentation of therapy received by patients (Element of Personal Medication Record); 2) Education and counseling, i.e. process of developing actions to achieve therapy goals by providing 
information related to the disease and use of DM drugs to patients based on leaflet material (Elements of Medication Therapy Review). Meanwhile, counseling is a consultative service by pharmacists regarding drug use and/or patient treatment problems (Elements of Medication Related Action Plan); 3) Drug monitoring, i.e. follow-up visit service provided by a pharmacist according to the patient's needs (Element of follow up) and providing interventions in case of treatmentrelated problems, which is documented in the pharmacist documentation book. The measurements of Post-MTM conditions are carried out after 30 days after the MTM administration. This research has obtained permission from the Health Research Ethics Commission of the Faculty of Medicine, Universitas Gadjah Mada with No: KE/FK/0710/EC/2019.

\section{Data Collection}

Sample collection was conducted through consecutive sampling i.e. samples which fulfilled the inclusive requirements i.e. the patients with type 2 DM age $\geq 18$ years old, patients who undergo regular check-up at least 1 month before the research, Patients who are willing to be the respondents, and having the promissory letter signed (informed consent), until the number of samples are complete. Furthermore, for patients who could not communicate properly or did not cooperate, patients whose jobs are the health worker, and patients who did not participate in this research till the end are not included in this research. Compliance data is obtained from the Morisky-Green Levine Medication Adherence Scale (MGLS) questionnaire. MGLS questionnaire was formerly developed by Morisky et al., to assess medication compliance toward anti-hypertensive regimen in the USA ${ }^{13}$. Moreover, the MGLS questionnaire also has been used to assess medication compliance within the study of other chronic illnesses such as diabetes ${ }^{14,15}$, cardiovascular diseases ${ }^{16}$, asthma ${ }^{17}$, and cancer $^{18}$. Quality of life assessment is using Diabetes Quality of Life Clinical Trial
Questionnaire (DQLCTQ). The DQLCTQ questionnaire used for assessing a patient's quality of life in this research is referred to previous research conducted by Hartati in 2003, in RSUP Dr. Sardjito whose validity test had been performed towards DM patients ${ }^{19}$.

The compliance and quality of life questionnaires were given to the patients before receiving MTM based service as PreMTM data. Furthermore, the DM patients would receive MTM based service from the pharmacist and upon receiving MTM based service in the next month according to regular checkup schedules which underwent in April 2020, the patients would be given the compliance and quality of life questionnaires once more as Post-MTM data.

\section{Intervention}

This research is an experimental one with intervention given in the form of MTM based service from the pharmacists to the DM patients. MTM based service that performed in this research was not a pure MTM instead it was a simplified form of MTM service according to the form made by BPJS as well as the elaboration of the existing theory of MTM. Therefore, it adapted according to the pharmacist's input and the needs of the community health center where the research took place. The form of implementation of MTM based service from the pharmacists including assessment, counseling, and education, as well as intervention/follow up toward DM patients delivered through medication record book. The medication record book consists of two books, the one which brought and kept by patients called "Smart and Control of DM medicine book" should be brought in every check-up contains MTR elements (demography, patient history, complaints, and physical examination), PMR (patient's medication-taking monitoring) and leaflet compiled by the research team and kept by the pharmacist "Documentation Book (Personal Medication Record)" contains the pharmacist's record about patient's medication and the intervention that had been performed. The objection of making this 
medication record book is simplifying and helping the pharmacist to implement MTM service in the community health center. The selection of the community health center of Tegalrejo, Jetis, and Gedongtengen as the place of research is based on the readiness of the health centers and the willingness of the pharmacist especially for implementing MTM based service, in this case the simplified form of MTM by the research team as well as the DM patient's prevalence in the health centers.

MTM based service delivered by the pharmacists of the health center to patients at the time of the patient's monthly check-up with implementation period of the MTM based service is one month. Before MTMbased services were applied to DM patients, pharmacists in each health center were provided training regarding the implementation of MTM-based services and Standard Operating Procedures for MTMbased services in the form of FGD. The pharmacists that participated in this research were three persons, who would deliver MTM based service to the patients and be helped by the researcher after the patients filled the PreMTM data in March 2020.

MTM based service was started with the assessment stage which was information gathering related to the patients' history, complaints, the recent medication the taking that was recorded on the assessment page of the smart book of medication control by the researcher. The result of physical/laboratory examination, allergy, comorbidity diseases, and herbal remedy consumption was recorded on monthly check-ups by the patients while the first recorded assisted by the researcher. Whereas the self-examination page contains the results of blood pressure and blood sugar measurement done by patients themselves and patient's medication schedule for a month on the therapy monitoring was recorded by patients. The second stage was initial education delivered by the researchers and for the next education were delivered by the pharmacists in the community health center while the patients receive their drugs. The educational material provided is based on the leaflet material, namely related to DM, the benefits of taking medication, how to use DM drugs, how to control blood sugar and the signs of side effects in using drugs in the smart book of medication control. Furthermore, when the drug was delivered, the pharmacist would reconfirm the information on the assessment page and the monthly check-up page written in the DM patient's smart book of medication control, identify drug problems and re-educate the patients regarding the disease and the medication of DM patients. Counseling would be given after that related to the patients' medication problems and/or complained of trouble from patients regarding the disease or current medication. The last stage was observation/follow-up done by the pharmacists toward patients' medication and making intervention if there any problem related to medication recorded by the pharmacists on the pharmacist's record book. Implementation period of MTM service was one month.

\section{Assessing Tools}

Compliance Degree

The questionnaire used for assessing the DM patients' compliance degree in this research is Morisky-Green Levine Medication Adherence Scale (MGLS). MGLS questionnaire is a free-access instrument for assessing compliance containing 4 questions items ${ }^{20}$, the answers for the items either "Yes" or "No", with the MGLS score result ranging from 0 to 4 . Compliance data obtained is in the form of the ratio, based on the lowest score (0) signifies the high compliance, score 1-2 signifies moderate compliance, and score 3-4 signifies low compliance. This MGLS questionnaire has been translated in Language Center of Faculty of Cultural Science, Gadjah Mada University.

According to previous research conducted by Wang et. $\mathrm{Al}^{13}$ the MGLS questionnaire had been validated and obtained the score of Cronbach's alpha $=0.62$, a proof that showed Morisky-Green Levine is a specific questionnaire for the compliance assessment $t^{13}$. Validation toward MGLS 
questionnaire in this research also has been performed through face validity method which tested $10 \mathrm{DM}$ patients in the community health center of Yogyakarta city, the location of this research. According to the result of MGLS questionnaire's face validity, > $80 \%$ respondents understood the question items and the language style. Moreover, there are no ambiguity in the questions of the MGLS questionnaire, the questions items are clear, respondents could answer the questions, the questions have been in a good order $(90 \%)$, and the words pronunciation are correct, as well as the interview period is short. From these results, it is expected that the MGLS questionnaire can be used to assess the patients' compliance degree.

\section{Quality of Life}

Diabetes Quality of Life Clinical Trial Questionnaire (DQLCTQ) is a questionnaire used to assess quality of life related to the wellness of DM patients. DQLCTQ covers 57 items consisting of eight domains. Complete DQLCTQ questionnaire data is scored, with a total range from 0 up to 100 . Score 0 signifies the lowest quality of patients' lives and 100 signifies the highest. Higher score signifies better wellness status.

The DQLCTQ questionnaire used for assessing patient's quality of life in this research refers to a previous research conducted by Hartati in 2003, in RSUP Dr. Sardjito, Yogyakarta toward Type 2 DM patients, with number of sample as much as 35 type 2 diabetes mellitus patients in RSUP dr. Sardjito which was conducted in January until March 2003. Validity and reliability tests including response, inter-item correlation, total item correlation, and internal consistency, as well as item status determination. The analysis results of complete item of the internal consistency value of all items, obtained valid and reliable results with a value of $\alpha=0.82(>0.7)$ based on the result, the DQLCTQ questionnaire can be used to assess type $2 \mathrm{DM}$ patients' the quality of life $^{21}$.

\section{Statistical Analysis}

The effect of MTM based service on medication compliance is analyzed with Wilcoxon test, while MTM effect on the quality of life analyzed with Paired T-Test, and for the characteristic effect on compliance and quality of life is using Ancova test with significance rate that can be used is $\mathrm{P}<0.05$. Patients' characteristics are depicted descriptively.

\section{RESULTS AND DISCUSSION} Patients Characteristics

This research was conducted in three community health centers that is Puskesmas Tegalrejo, Gedongtengen, and Jetis. The subject of Initial research were $38 \mathrm{DM}$ patients, however, the ones who participated in and met the inclusive requirements for this research fully (March-April 2020) were only 20 patients. Therefore, the analyzed total sample in this research was $20 \mathrm{DM}$ patients. The depiction of DM patients' characteristics in this research could be seen in Table I.

According to the characteristics data, this research was dominated by females as many as 15 people $(75 \%)$ and male as many as 5 persons ( $25 \%$ ), with the most age group is 55 64 years old and as many as 8 people (40\%). Sinuraya et. $\mathrm{al}^{22}$, in his research was also shown that the highest percentage of DM patients was female for about $>70 \%{ }^{22}$. Moreover, several other pieces of research also showed the DM patients prevalence toward females was much more than the male patients ${ }^{23-25}$. Generally, the increased risk of DM disease is caused by lifestyle changes that lead to reduced physical activity and increased obesity $^{6}$. This potentially more likely affects women for physically women are less active than men, with proportion as much as $27 \%$ for women and $20 \%$ for men who are categorized as physically inactive and represents a greater chance of increasing body mass index ${ }^{26}$. Furthermore, hormonal changes in women are much more than men especially related to premenstrual syndrome and post-menopause. Mauvais-Jarvis et al., ${ }^{27}$, suggest that there are changes to blood sugar homeostasis in the 
Table I. Characteristics of A Diabetes Mellitus Patient

\begin{tabular}{|c|c|c|}
\hline Characteristics & $\begin{array}{l}\text { Number of subjects } \\
(\mathrm{N}=\mathbf{2 0})\end{array}$ & $\begin{array}{c}\text { Percentage } \\
(\%)\end{array}$ \\
\hline \multicolumn{3}{|l|}{ Gender } \\
\hline Male & 5 & 25 \\
\hline Female & 15 & 75 \\
\hline \multicolumn{3}{|l|}{ Age } \\
\hline$<45$ years & 4 & 20 \\
\hline $45-54$ years & 6 & 30 \\
\hline $55-64$ years & 8 & 40 \\
\hline $65-74$ years & 2 & 10 \\
\hline \multicolumn{3}{|l|}{ Last education } \\
\hline Elementary School & 5 & 25 \\
\hline Junior High School & 5 & 25 \\
\hline Senior High School & 6 & 30 \\
\hline Diploma/Bachelor Degree & 4 & 20 \\
\hline \multicolumn{3}{|l|}{ Occupation } \\
\hline Employed & 8 & 40 \\
\hline Unemployed & 12 & 60 \\
\hline \multicolumn{3}{|l|}{ Marital Status } \\
\hline Married & 16 & 80 \\
\hline Widow & 3 & 15 \\
\hline Widower & 1 & 5 \\
\hline \multicolumn{3}{|c|}{ Duration of DM (duration of disease) } \\
\hline$<1$ years & 4 & 20 \\
\hline $1-5$ years & 6 & 30 \\
\hline $6-10$ years & 6 & 30 \\
\hline$\geq 10$ years & 4 & 20 \\
\hline \multicolumn{3}{|l|}{ Comorbidity disease } \\
\hline \multicolumn{3}{|l|}{ With comorbids } \\
\hline Hypertension & 6 & 30 \\
\hline Without comorbids & 14 & 70 \\
\hline
\end{tabular}

bodies of women who have experienced menopause ${ }^{27}$. The decreased ability to control blood sugar is related to decreased levels of estrogen in the body ${ }^{28}$. The age of the respondents is dominated by the 55-64 years age group, categorized as the elderly group. Similar to research by Wild et al., ${ }^{3}$, diabetics are in the 40-64 years age range, especially in the developing countries ${ }^{3}$. In that age range, the function of organs decreases including the pancreas' function which causes insulin production starts to decline and along with the lifestyle that begins to be less maintained.
The characteristics of patients without comorbids were 14 people $(70 \%)$ and patients with comorbid hypertension were 6 people $(30 \%)$. The result of this study is in line with the research conducted by Katadi et al.,24, Rokhman et al., ${ }^{23}$, that shows a number of DM patients with comorbid hypertension were found. The frequency of patients having diabetes for 1-5 years and 6-10 years has the same number of respondents, 6 people each $(30 \%)$. The last educational background of the respondents are 6 people $(30 \%)$ graduated from Senior High School, and the others 
Table II. The Effects of MTM-Based Services on Treatment Adherence to Diabetes Mellitus Patients

\begin{tabular}{|c|c|c|c|c|c|c|}
\hline \multirow[b]{2}{*}{ Treatment } & \multicolumn{3}{|c|}{ Compliance Degree } & \multirow{2}{*}{$\begin{array}{c}\text { Average } \\
\text { Compliance } \\
\text { Score } \pm \text { SD } \\
\end{array}$} & \multirow[b]{2}{*}{$\begin{array}{c}\text { Deviation } \\
\quad \pm \mathrm{SD}\end{array}$} & \multirow[b]{2}{*}{ P Score } \\
\hline & $\begin{array}{l}\text { High } \\
\text { N (\%) }\end{array}$ & $\begin{array}{c}\text { Average } \\
\mathrm{N}(\%)\end{array}$ & $\begin{array}{c}\text { Low } \\
\text { N (\%) }\end{array}$ & & & \\
\hline Pre MTM & 0 & $16(80)$ & $4(20)$ & $2.20 \pm 0.410$ & \multirow{2}{*}{$-0.4 \pm 0.50$} & \multirow{2}{*}{$0.005^{*}$} \\
\hline Post MTM & $6(30)$ & $12(60)$ & $2(10)$ & $1.80 \pm 0.616$ & & \\
\hline
\end{tabular}

Note: *level of confidence 5\% (P <0.05); Wilcoxon Analysis

graduated from Elementary School and Junior High School, 5 people each (25\%). People's educational background influences the behavior and their awareness of health. DM patients with lesser education tend not to recognize the symptoms of $\mathrm{DM}^{29}$. According to the employment status, 12 people $(60 \%)$ are unemployed patients, while 8 people $(40 \%)$ worked. The unemployed group in this study was dominated by housewives. The majority of respondents, 16 people $(80 \%)$, are married or have partners.

\section{The Effect of MTM-Based Services on DM Patient's Compliance}

This study was conducted to determine whether MTM-based services affect the adherence and quality of life of DM patients before and after conducted by pharmacists. MTM-based services are expected to increase medication adherence, and therefore a patient's quality of life is achieved with good results. The effect of MTM-based services on treatment adherence to DM patients in this study are shown in Table II. Assessment of medication adherence used the MGLS questionnaire, where the level of patient adherence was grouped into three categories: high adherence, moderate adherence and low adherence.

Based on the results in Table II, the increase of compliance is seen from the frequency obtained in each compliance category. Before the application of MTM, there were no patients who had a high level of adherence, and after the application of MTM there were 6 patients (30\%) with high levels of adherence. Patients with the moderate adherence before MTM are 16 people $(80 \%)$ and decreased to 12 people $(60 \%)$ after MTM, while patients with low adherence are 4 people $(20 \%)$ and decreased to 2 people $(10 \%)$. The average score of patient adherence in this study was $2.20 \pm 0.410$ before MTM-based services, and $1.80 \pm 0.616$ after MTM-based services. According to the results, the compliance score decreased with a deviation score of $-0.4 \pm 0.50$. Based on the measurement of adherence using MGLS, the lower the score obtained (score 3-4 for low adherence, 1-2 for moderate adherence, 0 for high adherence), the better the level of compliance. This shows that the treatment compliance of DM patients increased after receiving MTM-based services with a significance value obtained, $\mathrm{P}=0.005$ ( $\mathrm{P}$ $<0.05)$. From this statistical significance value, the MTM service provided by pharmacists affects the increase of DM patient compliance. Research conducted by Erku et al., ${ }^{10}$, revealed that the compliance of patients increased after receiving MTM services by pharmacists. The group of patients who were given MTM services had adherence from $9.2 \%$ to $61 \%$ after receiving MTM services ${ }^{10}$.

In addition, the study conducted by Bindu Murali et al.,2, obtained similar results, in which there was a significant increase after implementing MTM services $(\mathrm{P}=<0.05)$, initially $37.5 \%$ of the number of patients in the study who had high adherence and increased to $59.5 \%$ after being given MTM service and patients with low adherence decreased from $35.5 \%$ to $15.3 \%$. Ndefo et al.,30, also reported similar results, in which the average score of treatment adherence increased from 28.33 $(94.4 \%)$ to $29.22(97.4 \%)$. The MTM conducted 
Table III. The Effects of Patient's Characteristics to the Compliance Score Change in DM Patient Treatment

\begin{tabular}{lccc}
\hline Characteristics & Amount (N) & $\begin{array}{c}\text { Compliance Score } \\
\text { Change }(\Delta)\end{array}$ & P Score \\
\hline Gender & 5 & -1.00 & 0.670 \\
$\quad$ Male & 15 & -0.40 & \\
$\quad$ Female & & & \\
Age & 4 & -1.00 & 0.431 \\
$\quad<45$ years & 6 & -0.50 & \\
$\quad 45-54$ years & 8 & -0.38 & \\
55-64 years & 2 & -0.50 & \\
$\quad 65-74$ years & & & \\
Last education & 5 & -0.60 & \\
$\quad$ Elementary School & 5 & -0.80 & \\
$\quad$ Junior High School & 6 & -0.33 & \\
$\quad$ Senior High School & 4 & -0.50 & \\
$\quad$ Diploma/Bachelor Degree & & & \\
Occupation & 8 & -1.13 & \\
$\quad$ Employed & 12 & -0.17 & \\
$\quad$ Unemployed & & & \\
Duration of DM (duration of disease) & 4 & -0.75 & \\
$\quad<1$ years & 6 & -0.50 & \\
1-5 years & 6 & -0.17 & \\
6-10 years & 4 & -1.00 & \\
$\quad \geq 10$ years & & -0.50 & \\
Comorbidity disease & 6 & -0.57 & \\
$\quad$ With comorbids & 14 & & \\
Without comorbids & & & \\
\hline
\end{tabular}

Note: *The analysis used Ancova Test; level of confidence 5\% (P<0.05)

by pharmacists as part of the healthcare team led to a significant improvement in medication adherence $^{30}$.

The diabetes management program administered by pharmacists to patients also affects the improvement of patient's medication adherence in several previous studies. One of the studies is conducted by Manju et al., ${ }^{31}$, who attempted to find out whether the intervention given by pharmacists could improve treatment adherence to DM patients, measured before (Pretest) and after (Posttest) intervention. The interventions were education, counseling related to disease and medication as well as providing a chart of medication reminders that were asked to be brought to the next visit. Based on the measurement results, the poor adherence decreased from $48.2 \%$ to $26.1 \%$, moderate adherence increased from $32.1 \%$ to $39.1 \%$ and high adherence increased from $19.7 \%$ to $34.9 \%$ with significance value of $\mathrm{P}=0.000(<0.05)$ which indicates that the treatment adherence of DM patients increased significantly after pharmacist intervention ${ }^{31}$. Research conducted by Shareef and Fernandes ${ }^{32}$, and Butt et al.,33, also showed similar results, in which pharmacist intervention through education, counseling, and monitoring related to disease and DM therapy possess a significant effect in improving treatment adherence to DM patients. Various studies related to the intervention conducted by pharmacists show a good effect on patient 
medication adherence, which has the same result in this study that shows the effect of MTM services in increasing DM patient compliance. Research conducted by Bindu Murali et al.,$^{2}$, also shows that in addition to providing education and counseling, PMR, MAP, the diabetes calendars and/or leaflets provided as part of the MTM service program are effective in increasing the adherence of patient treatment.

The study shows that the level of patient adherence before being given MTM service by pharmacists, in which the level of patient adherence is moderate and low adherence, is lower than after MTM service. There are a number of factors that cause differences in treatment adherence in DM patients, one of which is patient's characteristics. Based on the data in Table III, without MTM-based service interventions (Pre and Post MTM), there is no difference in each group of gender characteristics on treatment adherence, with a significance value obtained of $\mathrm{P}=0.670$. Thus, gender characteristics do not affect changes in DM patient compliance scores. This study is similar to the one conducted by Rasdianah et $a l ., 34$, which shows that there is no difference in adherence levels between men and women statistically. However, based on the percentage of adherence, female patients have better treatment adherence than male patients. Male DM patients have a greater tendency to forget in taking medication than their female partners $(\mathrm{OR}=2.5, \mathrm{p}<0.05)^{35}$.

Patient's characteristics based on age in this study also shows that without MTMbased service interventions (Pre- and PostMTM), each group of age characteristics has no effect on treatment adherence, with a significance value obtained $\mathrm{P}=0.431$, or there is no effect of age characteristics towards changes in DM patient compliance scores. This result is the same with the study by Rasdianah et al., ${ }^{34}$, which shows that age has no effect on medication adherence. However, other studies reveal different results in which age affects a person's adherence. Nanda et al., ${ }^{36}$, stated that the level of adherence decreases with age because at an older age the patient's memory decreases so that they tend to forget to take medication.

Bindu Murali et al.,2, also revealed that there was a significant decrease in the level of adherence with increasing age $(\mathrm{P}=<0.05)$. Research conducted by Shams and Barakat ${ }^{37}$, also states that adherence of DM patients is lower in the elderly, this is because of the awareness towards the importance of therapy that decreases and patient's forgetful memory which also affects elderly patient's compliance. In contrast to several previous studies, the one conducted by Kubais et al., 38 , shows that patients aged between $36-50$ years showed the highest adherence while the 20-35 year age group showed low adherence to treatment. In this case, age can influence the treatment adherence of a person.

Based on the level of education, it shows that without the effect of MTM-based service interventions (Pre and Post MTM) there is no difference in each group of characteristics of the level of education on treatment adherence, with a significance value obtained, $\mathrm{P}=0.173$, which means there is no influence to changes in DM patient compliance scores. This result is different from the previous studies, patients with low educational status also had low adherence to treatment $(\mathrm{p}<0.05) .^{2}$. The educational level of a person can influence adherence because educated patients are more aware of the long-term consequences and complications of diabetes, as well as the need for proper blood sugar control. ${ }^{37}$.

Based on the job characteristics on this study, it shows that without the effect of MTM-based service interventions (Pre- and Post-MTM) there is no difference in each group of job characteristics on treatment adherence, with a significance value obtained $\mathrm{P}=0.516$, which means there is no characteristic effect work towards changes in DM patient compliance scores. These results are different from the studies conducted by Ainni in 2017 which showed the influences of work on patient treatment adherence ${ }^{39}$.

The duration of disease and comorbid characteristics in this study shows that without the influence of MTM-based service 
Rachma Malina, et al

Table IV. The influence of MTM-Based Services on Quality of Life for DM Patients

\begin{tabular}{cccc}
\hline Treatment & $\begin{array}{c}\text { Quality of Life Score } \\
\text { Average } \pm \text { up to }\end{array}$ & Deviation \pm SD & P Score \\
\hline Pre MTM & $73.82 \pm 7.918$ & $2.605 \pm 5.061$ & 0.033 \\
Post MTM & $76.42 \pm 5.623$ & & \\
\hline
\end{tabular}

Note $* 5 \%$ level of confidence $(p<0.05)$; Paired T-Test Analysis

interventions (Pre and Post MTM) there was no difference in each group of disease duration and comorbid characteristics on treatment adherence, with significance values of $\mathrm{P}=$ 0.605 and $\mathrm{P}=0.977$ respectively. It means that there are no influences of disease duration and comorbid characteristics on changes in DM patient compliance scores. This result is similar to the studies conducted by Srikartika et al., ${ }^{40}$, that there is no influence of disease duration and comorbidities on DM patient compliance.

Adherence to taking medication is important for DM patients to achieve treatment goals and prevent complications effectively. Good and correct medical therapy will be very beneficial for diabetes patients, especially for patients who are required to take the drug for a long time and for a lifetime. The difference in the results of this study with several previous studies can be due to the lack of the number of patients recruited and the uneven distribution of various characteristic groups, so that it cannot represent the level of adherence to treatment of DM patients. Although the analysis shows that the implementation of MTM-based services by pharmacists influences patient adherence in this study, other factors can also affect the level of adherence after receiving MTM-based services.

\section{The influence of MTM-Based Services on the Quality of Life of the DM Patients}

The quality of life of the DM patients is one of the therapeutic goals that must be achieved in DM management because DM is a chronic disease that requires prolonged therapy so that the effectiveness and side effects of the treatment can influence the quality of life of the patient. Assessment of the patient's quality of life uses the DQLCTQ, where the higher the score obtained, the better the quality of life. This study was conducted to see the effect of MTM-based services on the quality of life of the DM patients.

The results of the mean score of quality of life for patients before MTM were $73.82 \pm$ 7.918 to $76.42 \pm 5.623$ after MTM-based services with the difference obtained was $2.605 \pm 5.061$. These results show that there is an increase in the quality of life with the significance value obtained is $P=0.033$. Statistically, it can be interpreted that there is a difference in the average score of quality of life before and after MTM-based services, or in other words, MTMbased services have an effect on improving the quality of life of DM patients. Data on the influence of MTM-based services on the quality of life of DM patients can be seen in Table IV.

A study regarding the influence of MTM given by pharmacists on the quality of life of DM patients is still rarely conducted. A study that is mostly found is the studies related to the effect of pharmacist intervention other than MTM on improving the quality of life of the DM patients. Some of them are studies conducted by Septiar and Utami ${ }^{12}$, revealed that providing counseling by pharmacists for one month increased the quality of life score by $\mathrm{p}$ value $0.00(<0.05)$, which means that counseling by a pharmacist can improve the quality of life. Adepu et al. ${ }^{41}$, also revealed similar results, pharmacists who provide counseling to patients have an impact on improving patient perceptions of disease, lifestyle changes, and overall quality of life in diabetic patients. The counseling given by 
pharmacists to patients can be considered as an important element in implementing a DM disease management program ${ }^{41}$. One part of the MTM services is patient education and treatment counseling. Various studies related to the intervention conducted by pharmacists show that with pharmacist intervention, both education and counseling or MTM services can improve the quality of life of the patients.

The improvement of the patient's quality of life can be influenced by various factors, one of which is patient characteristics. In this study, the analysis of the effect of characteristics on changes in the quality of life score of DM patients can be seen in Table V. Based on the analysis of the characteristics of gender and age, it shows that without the influence of MTM-based service interventions (Pre and Post MTM) there is no significant difference in each group of characteristics towards the quality of life of DM patients with a significant value obtained, namely the quality of life of patients, a significance value is obtained respectively, $\mathrm{P}=0.185$ and $\mathrm{P}=$ 0.124 . In other words, the results of this study show that there is no effect of gender and age characteristics on changes in the quality of life score of the DM patients. This study is similar to the studies conducted by Ningtyas ${ }^{42}$, which shows that there is no effect of gender and age on the quality of life of type $2 \mathrm{DM}$ patients. Meanwhile, Gautam et al.,43, in its studies showed that women have a significantly lower quality of life than male patients. Men have a better quality of life compared to women, maybe because men are more accepting of the reality of diabetes, and have fewer complaints than women so that it affects their quality of life. ${ }^{21}$. Based on age, Adikusuma et al., ${ }^{21}$, also show a similar result in that there is no significant effect of age on the quality of life of the respondents with a significance value of $p>$ 0.05. Redekop et al., ${ }^{44}$, in its studies stated that patients with age more than 70 years, have the lowest quality of life than others, while the highest quality of life in patients aged less than 50 years. Younger people have a better quality of life because younger people have a more positive attitude towards their outlook on life than older patients ${ }^{44}$.

Based on the level of education, it shows that without the influence of MTM-based service interventions (Pre and Post MTM) there is no significant difference in each group of characteristics towards the quality of life of DM patients with a significant value obtained, namely $\mathrm{P}=0.090$. These results indicate that there is no influence of educational level characteristics on changes in the quality of life score of DM patients. In contrast to the study conducted by Ningtyas ${ }^{42}$, where the results of the education level factor analysis using logistic regression test obtained $\mathrm{P}=0.02$ with an Odds Ratio of 1.9 and 95\% Confidence Interval (1.11-3.09). These results indicate that there is an influence between the level of education and the quality of life of patients with type 2 diabetes mellitus, where type 2 diabetes mellitus patients who have a low level of education (elementary school) have a 1.9 times greater risk of having a lower quality of life (no satisfied) than those with higher education (SMA, College / Academy) ${ }^{42}$. On average, patients with low quality of life scores are patients with a lower level of education. Education is an important factor in improving the quality of life, because patients with good education will understand self-care and diabetes management, glycemic control, and self-assessment perceptions. ${ }^{45}$.

The results of the analysis of job characteristics also showed that without the influence of MTM-based service interventions (Pre and Post MTM) there was no difference in each characteristic group on the quality of life of DM patients with a significance value obtained, namely $\mathrm{P}=0.626$, meaning that there was no effect of job characteristics on changes in the quality of life score of DM patients. These results diverge from studies conducted by Zyoud et al., ${ }^{46}$ that patients who are unemployed have significantly lower quality of life scores. This finding is consistent with the results reported by Javanbakht et al., ${ }^{47}$ based on the quality of life score which indicates that 
Table V. The Effect of Characteristics on Changes in the Quality of Life Score of DM Patients

\begin{tabular}{|c|c|c|c|}
\hline Characteristics & Amount (N) & $\begin{array}{c}\text { Change in Score }(\Delta) \\
\text { Quality of Life }\end{array}$ & P Score \\
\hline \multicolumn{4}{|l|}{ Gender } \\
\hline Male & 5 & 6.10 & \multirow{2}{*}{0.185} \\
\hline Female & 15 & 1.44 & \\
\hline \multicolumn{4}{|l|}{ Age } \\
\hline$<45$ years & 4 & 6.85 & \multirow{4}{*}{0.124} \\
\hline $45-54$ years & 6 & 2.53 & \\
\hline 55-64 years & 8 & 0.89 & \\
\hline 65-74 years & 2 & 1.20 & \\
\hline \multicolumn{4}{|l|}{ Last education } \\
\hline Elementary School & 5 & 2.70 & \multirow{5}{*}{0.090} \\
\hline Junior High School & 5 & 2.88 & \\
\hline Senior High School & 6 & 4.47 & \\
\hline Diploma/Bachelor & 4 & -0.65 & \\
\hline Degree & & & \\
\hline \multicolumn{4}{|l|}{ Occupation } \\
\hline Employed & 8 & 5.20 & \multirow{2}{*}{0.626} \\
\hline Unemployed & 12 & 0.87 & \\
\hline \multicolumn{4}{|c|}{ Duration of DM (duration of disease) } \\
\hline$<1$ years & 4 & 1.65 & \multirow{4}{*}{0.643} \\
\hline $1-5$ years & 6 & 5.45 & \\
\hline $6-10$ years & 6 & -1.50 & \\
\hline$\geq 10$ years & 4 & 5.45 & \\
\hline \multicolumn{4}{|l|}{ Comorbidity disease } \\
\hline With comorbids & 6 & 0.87 & \multirow{2}{*}{0.573} \\
\hline Without comorbids & 14 & 3.35 & \\
\hline
\end{tabular}

Note: *The analysis used Ancova Test; level of confidence 5\% (P<0.05)

unemployment is associated with a higher likelihood of multiple or problems affecting the quality of life.

Based on the duration of the disease and comorbidities, it shows that without the influence of MTM-based service interventions (Pre- and Post-MTM) there is no significant difference in each group of characteristics towards the quality of life of DM patients with significant values obtained, namely $\mathrm{P}=0.643$ and $\mathrm{P}=0.573$. These results indicate that the characteristics of the duration of the disease and comorbidities have no effect on changes in the quality of life score of DM patients. Gautam et al., ${ }^{43}$, found that patients who had diabetes duration of more than 5 years had lower quality of life scores in all quality of life domains except in general health and mental health, which may be due to adaptation to a diabetic lifestyle. While, patients with comorbidities such as hypertension, statistically, show poor overall quality of life, health satisfaction, physical health, and psychological domains with lower quality of life scores. ${ }^{45}$.

Based on the results of the analysis of the influence of these characteristics, it shows that there is no difference in each characteristic group on the quality of life of DM patients. The improvement of the quality of life in this study was supported by the presence of patient factors who were adherent to their treatment 
after being given MTM services by pharmacists at the Public health center. In addition, patients who routinely conduct checkups, a healthy lifestyle, an understanding of the disease, and adequate DM treatment are factors that affect the quality of life of patients. The implementation of MTM-based services can facilitate the implementation of pharmaceutical services such as making it easier for pharmacists to monitor patient therapy, identify problems related to treatment, reduce the risk of adverse events related to drugs and based on study results show that the application of MTMbased services by pharmacists can improve adherence and quality of life of DM patients. So it is hoped that the application of MTMbased services by pharmacists at the Yogyakarta City Public Health Center can be conducted regularly and continuously.

\section{Research Limitations}

Researchers admit that this study still has many limitations, including the very limited sample size in this study, a short time interval for implementing and evaluating programs such as MTM services and the absence of a control group used as a comparison in this study. So that it cannot fully represent the success of the applied MTM-based services. In addition, the results from the measurement scale used to measure treatment adherence (MGLS) and the patient's quality of life (DQLCTQ) may have some drawbacks as this depends on the honesty of the study respondents in answering the questionnaire.

\section{CONCLUSION}

Medication Therapy Management (MTM) -based services provided by pharmacists to DM patients significantly improved treatment adherence $(\mathrm{P}=0.005)$ and patient quality of life $(\mathrm{P}=0.033) \mathrm{DM}$.

\section{REFERENCES}

1. Pinto SL, Kumar J, Partha G, Bechtol RA. Pharmacist-provided Medication Therapy Management (MTM) program impacts outcomes for employees with diabetes. Popul Health Manag. 2014;17(1):21-27.

2. Bindu Murali A, Boban B, Karoor Shanmughan A, Marimuthu K, Ramakrishnaneelatha A, Xavier A. Medication therapy management (MTM): An innovative approach to improve medication adherence in diabetics. Drug Metab Pers Ther. 2016;31(3):151-155.

3. Wild S, Bchir MB, Roglic G, et al.,. Global Prevalence of Diabetes Estimates for the Year 2000 and Projections for 2030.; 2004. http:// care.diabetesjournals.

4. RI K. HARI DIABETES SEDUNIA TAHUN 2018 Definisi Diabetes.; 2019.

5. Dinas Kesehatan. 2018_DIY_profilKESEHATAN-NARASI.; 2018.

6. Shaw JE, Sicree RA, Zimmet PZ. Global estimates of the prevalence of diabetes for 2010 and 2030. Diabetes Res Clin Pract. 2010;87(1):4-14.

7. Bluml BM. Definition of medication therapy management: Development of professionwide consensus. J Am Pharm Assoc. 2005;45(5):566-572.

8. Burns A. Medication therapy management in pharmacy practice: Core elements of an MTM service model (version 2.0). J Am Pharm Assoc. 2008;48(3):341-353.

9. Viswanathan M, Kahwati LC, Golin CE, et al.,. Medication therapy management interventions in outpatient settings: A systematic review and meta-analysis. JAMA Intern Med. 2015;175(1):76-87.

10. Erku DA, Ayele AA, Mekuria AB, Belachew SA, Hailemeskel B, Tegegn HG. The impact of pharmacist-led medication therapy management on medication adherence in patients with type 2 diabetes mellitus: A randomized controlled study. Pharm Pract (Granada). 2017;15(3).

11. Presetiawati I, Andrajati R, Sauriasari R. Effectiveness of a medication booklet and counseling on treatment adherence in type 2 diabetes mellitus patients. Int $J$ 
Appl Pharm. 2017;9:27-31.

12. Septiar ${ }^{1}$ HE, Utami ${ }^{2}$ P. Pengaruh Konseling Farmasis Terhadap Kualitas Hidup dan Kadar Gula Darah pada PAasien Diabetes Mellitus Tipe 2 di Puskesmas Gedongtengen Periode Maret-Mei 2014. J Farm Sains dan Prakt. 2015;1(1).

13. Wang Y, Lee J, Toh MPHS, Tang WE, Ko Y. Validity and reliability of a selfreported measure of medication adherence in patients with Type2 diabetes mellitus in Singapore. Diabet Med. 2012;29(9).

14. Al-Qazaz HK, Hassali MA, Shafie AA, Sulaiman SA, Sundram S, Morisky DE. The eight-item Morisky Medication Adherence Scale MMAS: Translation and validation of the Malaysian version. Diabetes Res Clin Pract. 2010;90(2):216221.

15. Sakthong $P$, Chabunthom R, Charoenvisuthiwongs R. Psychometric Properties of the Thai Version of the 8item Morisky Medication Adherence Scale in Patients with Type 2 Diabetes. Ann Pharmacother. 2009;43(5):950-957.

16. Shalansky SJ, Levy AR, Ignaszewski AP. Self-Reported Morisky Score for Identifying Nonadherence with Cardiovascular Medications. Ann Pharmacother. 2004;38(9):1363-1368.

17. Erickson SR, Coombs JH, Kirking DM, Azimi AR. Compliance from SelfReported versus Pharmacy Claims Data with Metered-Dose Inhalers. Ann Pharmacother. 2001;35(9):997-1003.

18. Tzeng JI, Chang C-C, Chang H-J, Lin CC. Assessing Analgesic Regimen Adherence with the Morisky Medication Adherence Measure for Taiwanese Patients with Cancer Pain. J Pain Symptom Manage. 2008;36(2):157166.

19. Hartati T. Kualitas hidup penderita dm tipe 2 perbandingan antara penderita kadar gula darah terkendali dan tidak terkendali. Published online 2003.

20. Beyhaghi H, Reeve BB, Rodgers JE,
Stearns SC. Psychometric Properties of the Four-Item Morisky Green Levine Medication Adherence Scale among Atherosclerosis Risk in Communities (ARIC) Study Participants. Value Heal. 2016;19(8):996-1001.

21. Adikusuma W, Farmasi A, Banjarmasin I, Perwitasari DA, Supadmi W. Pengukuran Kualitas Hidup Pasien Diabetes Melitus Tipe 2 yang Mendapat Antidiabetik Oral di Rumah Sakit PKU Muhammadiyah Bantul Yogyakarta Quality of Life Measurement of Type 2 Diabetic Mellitus Patients Who Gets Oral Anti Diabetic in PKU Muhammadiyah Bantul Yogyakarta. Vol 1.; 2016.

22. Sinuraya RK, Oktrina A, Handayani NK, Destiani DP, Puspitasari IM. Pelayanan Farmasi Klinis Meningkatkan Kontrol Gula Darah Pasien Diabetes Melitus. Indones J Clin Pharm. 2019;8(4):271.

23. Rokhman MR, Darakay CN, Raditya R. Pengaruh Pemberian Home Care Oleh Apoteker Pada Pasien Diabetes Melitus. Published online 2015.

24. Katadi S, Andayani TM, Endarti D. The Correlation of Treatment Adherence with Clinical Outcome and Quality of Life in Patients with Type 2 Diabetes. J Manaj DAN PELAYANAN Farm (Journal Manag Pharm Pract. 2019;9(1):19.

25. Yuwindry I, Wiedyaningsih C, Widodo GP. Pengaruh Pengetahuan Terhadap Kualitas Hidup Dengan Kepatuhan Penggunaan Obat Sebagai Variabel Antara Pada Pasien DM. 2016;6.

26. World Health Organization. Global Report on Diabetes. WHO press; 2016.

27. Mauvais-Jarvis F, Manson JAE, Stevenson JC, Fonseca VA. Menopausal hormone therapy and type 2 diabetes prevention: Evidence, mechanisms, and clinical implications. Endocr Rev. 2017;38(3):173-188.

28. Shepard M. Postmenopausal Women with Type 2 Diabetes: Better Glycemic Control with HT. NEJM J Watch. Published online 2001. 
29. Tao X, Li J, Zhu X, et al.,. Association between socioeconomic status and metabolic control and diabetes complications: A cross-sectional nationwide study in Chinese adults with type 2 diabetes mellitus. Cardiovasc Diabetol. 2016;15(1).

30. Ndefo UA, Aisha B; Moultry M, Davis PN, Askew R. Provision of Medication Therapy Management by Pharmacists to Patients With Type-2 Diabetes Mellitus in a Federally Qualified Health Center. Vol 42.; 2017.

31. Manju CS, Razak R, Chandni R, Athira B. PHARMACIST INTERVENTION IN MEDICATION ADHERENCE IN PATIENTS WITH TYPE II DIABETES MELLITUS. Int $J$ Pharm Sci Res. 2016;7(1):358.

32. Shareef J, Fernandes J. Evaluating the Effect of Pharmacist's Delivered Counseling on Medication Adherence and Glycemic Control in Patients with Diabetes Mellitus. J Diabetes Metab. 2016;07(03).

33. Butt M, Mhd Ali A, Bakry MM, Mustafa N. Impact of a pharmacist led diabetes mellitus intervention on $\mathrm{HbA} 1 \mathrm{c}$, medication adherence and quality of life: A randomised controlled study. Saudi Pharm J. 2016;24(1):40-48.

34. Rasdianah N, Martodiharjo S, Andayani TM, Hakim L. The Description of Medication Adherence for Patients of Diabetes Mellitus Type 2 in Public Health Center Yogyakarta. Indones J Clin Pharm. 2016;5(4):249-257.

35. Adisa R, Alutundu MB, Fakeye TO. Factors contributing to nonadherence to oral hypoglycemic medications among ambulatory type 2 diabetes patients in Southwestern Nigeria. Pharm Pract. 2009;7(3):163-169.

www.pharmacypractice.org

36. Nanda OD, Wiryanto B, Triyono EA. Hubungan Kepatuhan Minum Obat Anti Diabetik dengan Regulasi Kadar Gula Darah pada Pasien Perempuan Diabetes Mellitus. Amerta Nutr.

$$
\text { 2018;2(4):340. }
$$

37. Shams MEE, Barakat EAME. Measuring the rate of therapeutic adherence among outpatients with T2DM in Egypt. Saudi Pharm J. 2010;18(4):225-232.

38. Kubais MN Al, Hassan NAGM, Shamsain MH. Assosiation Between Adherence to Diabetes Medication and Glycemic Control. Int J Res Dev Pharm Life Sci. 2015;5(1):1915-1920.

39. Ainni AN. Studi Kepatuhan Pengobatan Penggunaan Obat Pada Pasien Diabetes Melitus Tipe 2 Di Instalasi Rawat Jalan RSUD. Dr. Tjitrowardojo Purworejo. Published online 2017.

40. Srikartika VM, Dwi Cahya A, Suci R, Hardiati W. Analisis Faktor yang Memengaruhi Kepatuhan Penggunaan Obat Pasien Diabetes Melitus Tipe 2. J Manaj dan Pelayanan Farm . 2016;6(3):205-212.

41. Nagavi B, Adepu R, Rasheed A. Effect of patient counseling on quality of life in type-2 diabetes mellitus patients in two selected South Indian community pharmacies: A study. Indian J Pharm Sci. 2007;69(4):519. doi:10.4103/0250474X.36937

42. Wahyu Ningtyas D, Pudjo Wahyudi dr, Prasetyowati I. Analisis Kualitas Hidup Pasien Diabetes Melitus Tipe II Di RSUD Bangil Kabupaten Pasuruan (Analyze Quality of Life in Patients With Type II Diabetes Mellitus at Public Hospital of Bangil, Pasuruan).; 2013.

43. Gautam Y, Sharma AK, Agarwal AK, Bhatnagar MK, Trehan RR. A crosssectional study of QOL of diabetic patients at tertiary care hospitals in Delhi. Indian J Community Med. 2009;34(4):346-350.

44. Redekop WK, Koopmanschap MA, Stolk RP, Rutten GEHM, Wolffenbuttel BHR, Niessen LW. Health-Related Quality of Life and Treatment Satisfaction in Dutch Patients With Type 2 Diabetes. Vol 25.; 2002.

45. Issa B, Baiyewu O. Quality of Life of 
Patients with Diabetes Mellitus in a Nigerian Teaching Hospital. Hong Kong J Psychiatry. Published online 2000.

46. Zyoud SH, Al-Jabi SW, Sweileh WM, et al.,. Relationship of treatment satisfaction to health-related quality of life among Palestinian patients with type 2 diabetes mellitus: Findings from a cross- sectional study. J Clin Transl Endocrinol. 2015;2(2):66-71.

47. Javanbakht M, Abolhasani F, Mashayekhi A, Baradaran HR, Jahangiri noudeh Y. Health Related Quality of Life in Patients with Type 2 Diabetes Mellitus in Iran: A National Survey. PLoS One. 2012;7(8):e44526. 